\title{
Effect of Mortgage Financing and Affordability on the Performance of Public - Private Partnership in Housing Provision
}

\author{
KALU, Joseph Ufere (Corresponding author) \\ Mohammed Ishaq M.; Adeyemi A. and Ahmed Abdullahi \\ Department of Estate Management and Valuation; Faculty of Environmental Technology \\ Abubakar Tafawa Balewa University, Bauchi, Bauchi State, Nigeria
}

\begin{abstract}
The study examined the performance of Public-Private Partnership (PPP) option as a veritable means for public housing delivery. The study aimed at examining the effect access to mortgage finance and housing affordability has on the performance of Public - Private Partnership in housing provision, with a view to modifying to achieve the desired objective. The study adopted the quantitative approach, data was collected through questionnaire survey from occupants of PPP estates, who were randomly selected from three housing estate. A total of 1050 close-ended questionnaires were distributed to the occupants. The results show that $64.7 \%$ variations in the performance of PPP housing schemes was explained by affordability of housing and mortgage finance accessibility. The regression analysis reveals that housing affordability and mortgage finance significantly influenced the performance of PPP housing provision such that a change in housing affordability causes a $98.6 \%$ positive change in the performance of PPP housing provision, while there is an inverse relationship between access to mortgage finance and performance of PPP housing provision scheme, up to $70.8 \%$. The implication is that as housing affordability is a strong driver of performance of PPP as a means for housing provision; but access to mortgage finance has a negative effect on the performance of PPP, this may be imply that mostly equity was used in the acquisition of PPP housing units since it was affordable to occupants. The study recommended that the government should come create enabling environment for PPP promoters to provide affordable housing units to the populace which will justify PPP as a veritable public housing scheme and help reduce the massive housing deficit being experienced in the country.
\end{abstract}

Keywords: Housing, Mortgage Finance, Public-Private Partnership

DOI: $10.7176 /$ PPAR/11-7-06

Publication date:September 30th 2021

\section{INTRDUCTION}

Globally, housing is delivered through various means to provide the shelter needs of people. Prior to liberalization of many economies, governments were actively engaged in the provision of shelter to its citizen. This is normally provided through direct public construction of social housing and low cost housing. However, with increased urbanization, direct government provision of housing becomes rather inadequate and not sustainable (Liu, Chan, \& Wang, 2014). Alternatively, various private engagements in housing provision come to the fore. These include sole private housing developments, cooperative housing, build and service schemes, and lately Public Private Partnership (PPP). With the exception of the PPP arrangement, the other housing strategies are either purely public or private and therefore have various limitations. PPP strikes a balance between the extremely public arrangement in one hand and purely private arrangement on the other hand. That is why it's regarded as an innovative alternative housing solution for housing dilemma in the 21st century (Amann, 2010; Kutuma, 2017).

Public-Private Partnerships are relationships established between public entity and private sector organizations with the aim of delivering an infrastructure facility. It is the merging of the public sector and private organization advantage in order to achieve a certain goal for the benefit of the society. These arrangements usually take a long period of time. Hodge \& Greve (2017) states that PPP can cover hundreds of different types of long term contracts with a wide range of risks allocations, funding arrangement and transparency requirements. It is evident in Nigeria, like other developing nations, that the conventional housing provision strategies are inadequate to cater for the housing needs of the populace. This is evident in the huge housing deficit of about 17-23 million. This has become necessary because the only major revenue source to the country is the crude oil which has lost value in the international market and it accounts for $70 \%$ of government income (Goussard 2015). Thus, government cannot unilaterally provide the housing need of the populace without private sector participation (Amann, 2010; Eziyi O Ibem \& Aduwo, 2012).

The PPP model was shown to be very effective, innovative, and sustainable at least in the advanced 
nations (Tagliaro, 2014). However, the result is different in most developing nations (Bolaji, 2017; Sani, Sani, \& Ahmed, 2018). The level of implementation of the PPP housing project is rather abysmal, ineffective and costly (Eziyi Offia Ibem, 2011; Jiya et al., 2018; Sani et al., 2018; Trangkanont \& Charoenngam, 2014). The cost of most PPP housing arrangement in developing nations is reported to be exorbitantly high beyond the reach of low income earner thereby affecting housing affordability adversely (Olanrele et al., 2019; Shaqra, Badarulzaman, \& Roosli, 2015; Sobuza, 2010). Housing affordability is the ability of ones income to acquire houses without exerting significant burden on his ability to meet the other daily need (Kutuma, 2017; Murphy, 2014). The higher the cost of a house, the higher would be its unaffordability which may affect the prospect of selling the houses. Therefore, higher unaffordability means lower demand which may also lower the supply of housing in a long run (Gandhi, 2012; Tsai \& Peng, 2012).

Niger state government has launched housing programmers in partnership with the private organizations (Jiya et al., 2018). These arrangements have delivered numerous housing projects with attendant successes and challenges. It is therefore against this background that this study seeks to evaluate the effect of mortgage accessibility and housing affordability on the performance of PPP housing provision in Minna metropolis, Niger state, Nigeria.

The aim of this study is to determine the effect of mortgage finance accessibility and housing affordability on the performance of Public-Private Partnership housing provision.

\subsection{LITERATURE REVIEW}

\subsubsection{Housing Finance}

Housing finance is a financial service delivery approach where different types of intermediaries compete to deliver 3 main activities as funding, lending and servicing of real estate development. Finance is one of the most significant factor in housing production and delivery as with available finance all other factors of housing delivery can be acquired (Okpala, 1994).

IFC (2008) states that housing finance has engage in a significant activity in the world Bank's overall financial sector strategy and it is clearly and inextricably linked to the over- arching mission of reducing poverty and improving living standard. In Mexico, the housing finance market is assessed by factors such as demographic and economic, housing stock and ownership, housing out comes and efficiency of housing and housing related market (Lopez-Silva et-al 2001)

Housing sector generally has the potentials to grow the economy of any nation at about 1.4 times of a given rate of economic development as it will generate 3.2 million jobs over a decade (WBG, 2008). Housing finance has been in practice over the years and takes various forms. These are Non institutional and Institutional sources of housing finance.

\subsection{Concept of Mortgage Finance}

Mortgage from its origin refer to a deed pledge. The dead portion of a mortgage entails that, the pledge dies as soon as the loan taken is repaid and that property which serves as collateral in the transaction was dead or forfeited, if the loan was not repaid by the person to whom the loan was granted.

Mortgage finance is a long term loan at market interest rates extended by a formal sector financial institution typically one that specialized in housing such as Building society that qualifies mortgagers based on underwriting criteria (Ferguson 1999). It is a conditional sale of property collateral where a creditor held title while the debtor can sell that property for the recovery of the loan granted in case of default. The performance of mortgage are as illustrated in the diagram below;

Mortgage has over the years increase access to housing in many countries of the world especially in the developed countries by the citizens with low and medium incomes as the major beneficiaries. However, there is still inadequate acceptance of the mortgage system and there exist low penetration.

Due to the forgoing, resources are allocated primarily to nations with low mortgage penetration rates which are in high need. Verily, in line with significant role and limited resources available which requires a strategic allocation and coverage gap of countries with minimum access to housing finance is in the increase (WBG, 2016).

There is also Islamic approach to mortgage financing to ensure access to affordable housing finance. In Islamic mortgage finance, the approach to housing finance is based on principles of partnerships as identified by various scholars as discussed below.

\subsection{Mortgage Accessibility}

These are pre-determined set of contractual requirements by mortgage financing institution to be met by 
a mortgage applicant to secure mortgage financing in order to acquire a property. They vary from country to country and from one financial institution to the other.

The financing structure determines the lenders requirement, hence the choice of financing bank (Ojo \& Ighalo, 2008). Ismail et. al. (2014) provide that, the choice requirement for home loan market in Greece are; quality of service rendered, interest rate, loan amount, previous relationship, location, lower queue, pleasure period and advice are significant factors in choosing bank for home financing while reputation, service quality, religious belief, media advertisement and social influences are considered as the most significant factors that affects selection of Islamic home financing.

\subsection{Housing Affordability}

Affordable housing has several meanings by various scholars. The essence of affordable housing is to increase access to a medium quality housing for average income earners of the society and that their income can support repayment over a long period without jeopardizing other necessities of life. Evans et. al, (2007) opined that, affordable housing for people whose income is a certain percentage below the median income for an area where government provides incentive and cash assistance to developers to build new affordable housing or rehabilitate older apartment buildings or other projects and offer housing at rates deemed affordable for the area.

Affordability is a public policy target that is in three dimensional space measured by home prices, household income, and mortgage interest rates (Trimbath \& Montaya, 2002).

In some countries of the world, efforts are made in order to make houses affordable by reducing the average living space. The per capital average living space in China was reduced from $4.50 \mathrm{~m} 2$ to $3.60 \mathrm{~m} 2$ from 1952 to 1978 ( Zhihun Zhou, 2015). In the United States, the term housing "is used to describe housing, rented or owner - occupied that is affordable no matter what one's income is". The U.S. government regard housing cost at or below $30 \%$ of one's income to be affordable (affordablehousingonline.com retrieved $6^{\text {th }}$ September 2019).

In 2016, David Cameroun, the then Prime Minister of UK states that from the government point of view, Affordable housing of rent should cost not more than $80 \%$ of average local market rent and if it comes to home ownership, it must be provided at a price level at which mortgage payments on property should be more than would be paid rent on council housing but below market level. Furthermore, Housing Charity Shelter opined that, affordable housing should cost not more than $35 \%$ of household income after tax and benefits. The Green paper on Housing for many 2018 define affordable housing to mean a house or flat built with some public backing at a price that means those who live in it have enough money left after housing cost for other things they need. However, the term affordable has been so abused that affordable is linked to people's income not to market prices.

\subsection{Factors Influencing Housing Affordability}

Nwuba et. al. (2015) opined that, household income, savings, construction period, and education level are the major determinants of housing affordability in Nigeria's urban housing markets. Yang and Wang (2011) state that, in their research on the privatization of public housing problem as it relates to housing affordability hinged on household family structure, educational attainment and employment status.

In Malayasia, income, property prices, land cost, demand and supply are identified as the factors influencing affordability of housing (Yap et. al., 2018). Raphael and Akumu (2018) provided that, Households' socio-economic factors, property attributes, loan characteristics, and macro-economic environment plays a major role in housing affordability. In specific terms, interest rate on mortgages, households' dependents quantity, loanto-ratio value ratio, type of mortgages instrument, quantity of households; income earners, real gross domestic product per capital and size of household influence housing affordability in Kenya.

The National Housing Fund which provides lowest interest rate in Nigeria for mortgages at $6 \%$ is bedeviled with operational challenges that includes among others as non-disbursement of National Housing Funds application loans as a result of non fulfilment of some unbearable conditions, lack of submission of an acceptable security of existing mortgage loans by Primary Mortgage Banks, perfection of mortgage funds delay and inability of PMBs to fund $20 \%$ of loan as one of the statutory requirements. (Chiomuna, 2000, Bichi, 2002, \& Fortune Ebie, 2004). 


\subsection{Public-Private Partnership Arrangements}

Yunusa (2013) States that, Malaysia, Zimbabwe and Malawi have as individual nations demonstrated that, Public Private Partnership with states have provide housing access for low income earners. Public Private Partnership and in addition to community based organizations have been successful towards housing delivery for urban centers low income earners and this effective arrangement played key role for the increase in access to housing (UN-Habitat, UNON Press 2007).

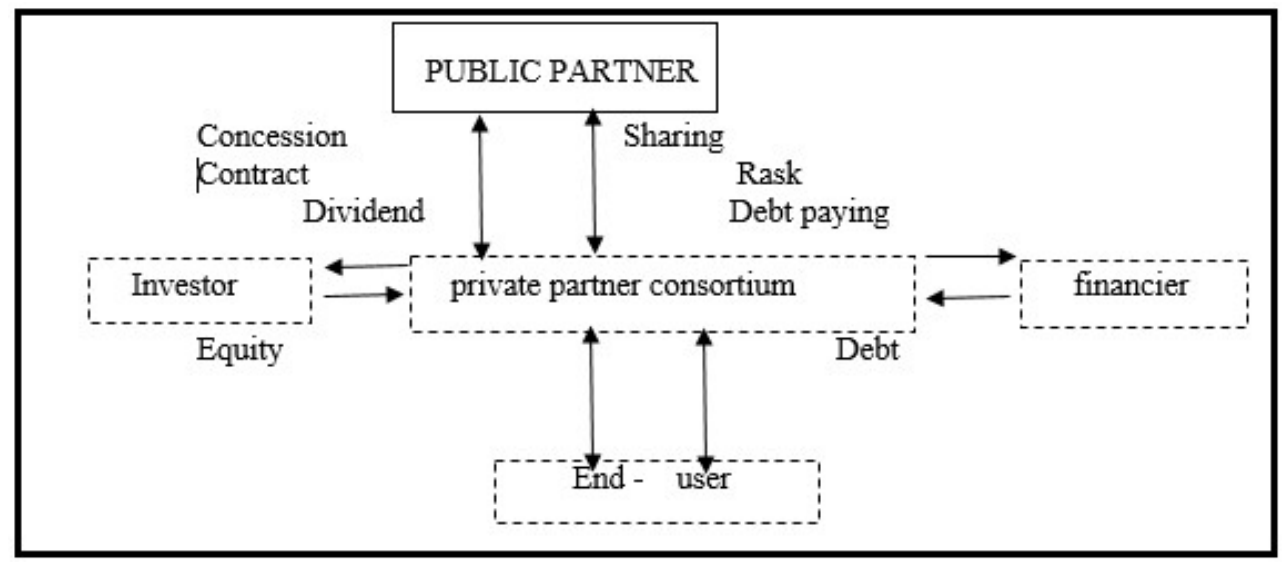

Source: Yauhang and Hongui (2018)

Figure 2: Schematic cementation of a public private partnership project

There are various models of Public- Private Partnership arrangements. These are; Design Bid-Build, Design - Build, public contract fee service, maintenance contract, construction manager at risk, design-build with warranty, design-build-operate-maintain, build-operate-transfer, build-transfer-operate, design-build-finance, design-build-finance operate, design-build-finance-operate-maintain, long term lease agreement, concessions build-own-0perate, Asset sale (Bauxbaim \& Ortiz, 2009)

Liang and Wang (2019) opined that, various types of Public Private Partnership model of project actualization among which are; concessionaire contract are chosen such as Build-Own-Operate, (BOO) BuildOperate-Transfer (BOT), Build-Own-Operate-Transfer (BOOT), Design-Build-Operate (DBO), DesignBuilding-Financing-Operate (DBFO), and their variances.

The Canadian Council for Public Private Partnerships, (2011) identified models of public private partnerships project delivery as thus; privatization, concession, build-own-operate-transfer, Design-buildfinance-operate-maintain, Design-build-finance-operate, Design-build-finance-operate and maintenance, contract, finance only, Design build

\subsubsection{Critical Successful Factors for Partnerships Projects}

Public Private Partnership projects suffer setback as it accounts for about $15 \%$ and $18 \%$ of infrastructural cost expended in U.K and Australia respectively (Emst \& Young, 2005).

Edwards et. al. (2005) grouped critical success factors of Public Private Partnerships in the UK construction industry as effective management, project implement ability, government guarantee, favorable economic condition and available financial market. Ismail et. al. (2011) provides that, the critical success factors in Malaysia are good governance, appropriate risk allocation and legal framework favorability.

In Thailand, the recognized critical factors in low cost Public Private Partnership housing project are policy pressure, procurement process and inappropriate contractors while the barriers to a successful Public Private Partnership are negative outcomes, power and status, differentiations, organizational conflicts and difficulty in merging values and cultures. In Nigeria, the success factors that influence Public Private Partnership projects are equitable risk allocation, stable political system and reputable developer (Muhammad et-al., 2018).

Tanhang and Hougwu (2018) opined that, the success factors of a Public Private Partnership project must meet 3 objectives namely; Short term goals; design and construction stages of projects, satisfaction of stakeholders which can be assessed at the end of the concession contract, ensure benefit to the whole industry and social development.

\subsubsection{Public- Private Partnership Housing Project Performance}

Performance measurement is an act carried out to gauge how well or the progress recorded of service or project delivery in an organisation. It is a way by which divergence from the actual return are identified against the required return from investment. Performance measurement are also refer to as key performance indicators 
(Li, 2016)

Oyigbo and Ugwu (2017) stated that, key performance indicators are specific milestones or components of performance measures that serve as gauge to indicate progress towards the eventual achievement of a target. Performance measures are the broad classification of desired outcomes required of the concessionaire. Key performance indicators includes among others as targets, benchmark, milestones, dates, numbers, percentage, variance, distributions, rates, time, cost, indexes, ratios, survey data, and report data.

The effective and decisive method to ensure sustainability of Public-Private Partnership project is through performance measurement from the life cycle perspective with management of stakeholders involved must agree. These stakeholders are developer, contractor, local community and potential stakeholders identified to ensure their contribution to the economic, environmental and good performance throughout the life cycle of the project (Liang \& Wang, 2019).

Furthermore, in value for money approach to project evaluation and performance measurement is based on an extension of the popular 3Es known as 4Es and these were opined. The 4Es are recognize as a means of project assessment and entails that for any project to be successful, the managers must have Economy, Efficient. Effectiveness and Equity also serve as foundation to measure performance on project delivery.

\subsection{Conceptual Framework}

The aim of the research is to determine the influence of mortgage finance and housing affordability on performance of Public Private Partnership housing projects in Niger state. Thus, from the conceptual underpinning deducted from the review of previous literatures, mortgage financing (Ali, Ismail, \& Bakri, 2013; Campbell, 2012; Pal \& Hossain, 2014) and housing affordability (Ajayi et al., 2016; Gibb, 2011; McCord, McGreal, Berry, Haran, \& Davis, 2011; Phang, 2010; Tagliaro, 2014) are related to the performance of PublicPrivate Partnership (PPP) housing projects (Ajayi et al., 2016; Gandhi, 2012; Jiya et al., 2018; Ojebode, 2016). Thus, mortgage financing and housing affordability are conceptualized to be the independent variables of the research. The performance of PPP housing projects, on the other hand, is conceptualized to be the dependent variables of the study. The interrelationships among the research constructs are presented as a conceptual framework

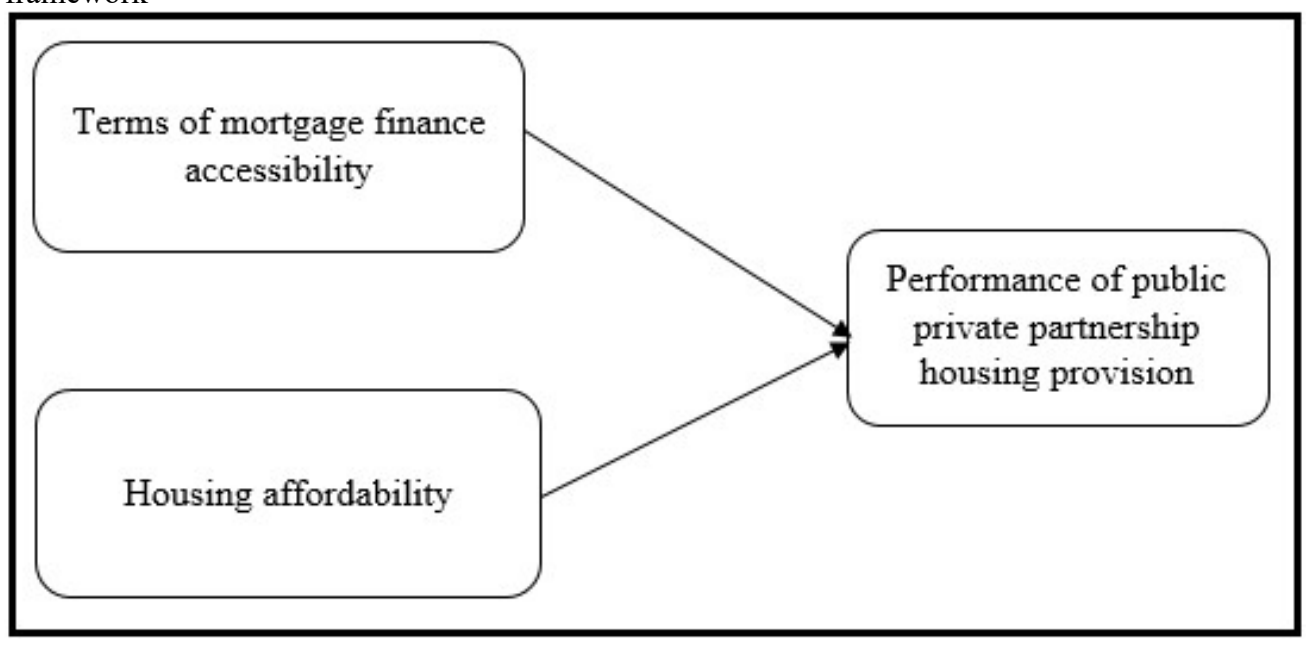

Figure 3: Conceptual Framework

\subsection{Research Methodology}

\subsection{Sampling Size}

This is an important feature of any empirical study whereby the aim is to make inferences. It deals with the determination of choosing the number from the entire population. Towards achieving this, Krijcie and Morgan (1970) table of sample size determination was used to determine the sample size of for the Civil Servants beneficiaries of PPP houses. For the private developers and mortgage banks, the entire two (3) developers and two (2) mortgage banks were selected for the study.

\subsection{Data Collection Instrument}

This research used questionnaire to collect data from the respondents. . 


\subsection{Method of Data Presentation and Analysis}

The collected data were analyzed using both descriptive and inferential statistics. The objective which sought to determine the effect access to mortgage finance and level of housing affordability on the performance of Public-Private Partnership in housing provision in Minna were analyzed, using Pearson correlation and multiple regression analysis.

\subsection{Results and Discussion}

There are 1,050 housing units delivered at three different locations within the city subject of this research work. In accordance to Krejcie- morgan population and sample size table, 1,050 is the total population and the sample size in this case is 278 , but a total of 310 questionnaires were prepared and administered to cover for short falls. This is as shown in table 1.

Table 1: Questionnaire administration

\begin{tabular}{lcc}
\hline Description & Quantity & Percent (\%) \\
\hline Number of questionnaire distributed & 310 & 100 \\
Number of questionnaire filled, returned and used & 288 & 92.90 \\
Number questionnaire not returned & 22 & 7.10 \\
\hline
\end{tabular}

\subsection{Effect of mortgage finance accessibility and housing affordability on PPP Housing Provision}

The study examined the effect of access to mortgage finance and housing affordability on the performance of PPP housing Delivery projects. The study utilized ratio of income-mortgage premium as a construct for affordability level, annual repayment as a proxy for mortgage finance and total number of housing units accessed as a construct for PPP housing performance.

Table 2: Summary of Multiple Regression Model

\begin{tabular}{llrrrrrr}
\hline Model & R & R Square & Adjusted R Square & $\begin{array}{l}\text { Std. Error of the } \\
\text { Estimate }\end{array}$ & F & p-value \\
\hline 1 & $.804^{\mathrm{a}}$ & .647 & .592 & 454818.251 & 11.891 & .001 \\
\hline
\end{tabular}

Table 2 showed the overall significance effect of the model employed for the study. The result revealed that $64.7 \%$ variation in PPP housing performance can be explained by affordability and mortgage finance factors, In other words, housing affordability and mortgage finance explains $64.7 \%$ significant effect of the performance of PPP housing provision. The overall significance of the model depicted by the F-statistics is statistically significant at $p$-value $(0.001)$ is less than level of precision at 0.05 . This indicates the model fit for the purpose of determining the effect of mortgage finance and affordability on the Performance of PPP as housing provision scheme is supported.

Table 3: Regression Coefficients Results

\begin{tabular}{|c|c|c|c|c|c|c|}
\hline \multirow{2}{*}{\multicolumn{2}{|c|}{ Model }} & \multicolumn{2}{|c|}{ Unstandardized Coefficients } & \multirow{2}{*}{$\begin{array}{c}\text { Standardized } \\
\text { Coefficients }\end{array}$} & \multirow[t]{2}{*}{$\mathrm{T}$} & \multirow[t]{2}{*}{ Sig. } \\
\hline & & $\mathrm{B}$ & Std. Error & & & \\
\hline & (Constant) & 364582 & 275073 & & 1.325 & .208 \\
\hline & Affordability & .986 & .908 & .842 & 1.087 & .040 \\
\hline & Mortgage Financing & -.708 & .335 & -.043 & -2.116 & .048 \\
\hline
\end{tabular}

The result of regression presented in table 3 revealed that Housing affordability and mortgage financing significantly influence the performance of PPP housing provision such that a change in housing affordability causes a 98.6\% positive change in the performance of PPP housing provision. Furthermore, there is an inverse relationship between mortgage financing and performance of PPP housing provision model, up to $70.8 \%$. This finding corresponds with the following studies Bauxbaim \& Ortiz 2009, Chuma \& Eheghe, 2017, Muhammad et al., 2018; were reported one positive and one negative beta value in their analysis and the result showed insignificant with the above recommended value of 0.000 . However, this result is not in line with that of Wall and Martin 2003, Oyigbo and Ugwu 2017, which reported a negligent effect of housing affordability on PPP housing provision. 


\subsection{Summary of Findings}

This study submits that $64.7 \%$ variation in PPP housing performance is attributed to both housing affordability and access to mortgage finance. In other words, affordability and mortgage finance have $64.7 \%$ significant effect on PPP housing performance. This, therefore shows that, performance of PPP housing provision depends on level of affordability which is subject of income level and mortgage financing options covered in interest on mortgage loans, mortgage sum and repayment period.

\subsection{Conclusion}

The study concludes that the performance Public-Private Partnership as a veritable housing provision vehicle is directly linked to housing affordability and inversely related to mortgage financing accessibility. Therefore the study determining the effect of mortgage finance accessibility and housing affordability on the performance of PPP as Housing Provision pattern in which the study revealed that affordability and mortgage finance explains 64.7\% significant effect on PPP housing provision in the study area. The study further identifies a positive and negative regression beta value coefficients where affordability level and mortgage financing significantly influence the performance of PPP housing provision such that any change in affordability level of respondents will cause $98.6 \%$ positive change in the performance of PPP housing provision and mortgage financing, responsible for up to $(70.8 \%)$.

\subsection{Recommendations.}

In line with the research findings and challenges inherent therein, the under listed suggestions may suffice as a way forward for sustainable PPP housing provision in the study area and Nigeria in general.

These are

i. It is also recommended that government create enabling environment for use of PPP in public housing provision subject to the provision of affordable housing units.

ii. Furthermore, Public policy should introduce support strengthening the current PPP legal framework to accommodate new realities and to curtail unfriendly behavior and attitude of developers and investors.

\section{References}

Abdullahi (2017). The role of mortgage financing in Public-Private Partnership (PPP) Housing Delivery in Niger State, Nigeria, PGD Project Abubakar Tafawa Balewa University, Bauchi, 2017

ADB, (2018). Asian Development Bank, Public Private Partnerships Guidance note on Procurement No TIM 189410-2

Ajayi, O., Ajayi, O., Akinsiku, O., \& Osunsanmi, T. (2016). Strategies for housing affordability in Nigeria. Journal of Construction Project Management and Innovation, 6, 1620-1632.

Albarto (2019), Setting the context; Mexico Housing Finance International, September.

Ali, R., Ismail, S., \& Bakri, M. H. (2013). A Comparative Analysis of Conventional and Shari'ah for Residential Mortgage-backed Securities. Procedia Economics and Finance, 7(Icebr), 116-125. http://doi.org/10.1016/S2212-5671(13)00225-6

Alter C. and Hage, (1993).Organization working together. New buy park calif: Sage publications,

Amann, W. (2010). New Policies to Facilitate Affordable Housing in Central and Eastern Europe. Acta Polytechnica, 50(1), 53-56.

Bolaji, S. (2017). Public Private Partnership (PPP) for Housing Delivery to the Low Income Civil Servants in Abuja, Nigeria. Journal of Varna University of Economics, 61(2), 144-157.

CAHF (2019). Economic of Housing in Nigeria, Addressing Housing Demand in the face of Growing Joblessness and Income Inequality; A paper presented at Annual Abuja Housing show and Conference, Abuja, Nigeria.

Campbell, J. Y. (2012). Mortgage Market Design. Review of Finance, 17(1), 1-33. http://doi.org/10.1093/rof/rfs030

Carol P. and Steane P, (2000), ` Public Private Partnerships: Sectorial Perspectives. In S.P

CBN, (1999), Overview of the Financial Sector on the eve of Central Bank of Nigeria.

CBN, (2017), Nigerian Housing Financing Program: A paper Presented by Director of other Financial Institutions Supervision Department, at Abuja International Housing Show $15^{\text {th }}$ July 2017.

The Canadian Council of Public-Private Partnership, (2001), Benefits of Water Services the Canadian council of Public Private Partnerships

Claudettie \& Sirman, (2006), Mortgage Finance as solution to Housing Problems, Procure Intelligent interesting, Vol. 1, Pp 12 - 27 November 27, 2006.

Christianson et-al 2007 
Clauretie and Webb, (1993), The Theory and Practice of Real Estate Finance” The Drydeen U.S.A.

Collins et-all (2009), Journal of Policy Analysis and Management. Vol. 30, No 2, 216-232, Association of Policy Analysis and Management.

Creswell, J. W. (2014). Research design: qualitative, quantitative, and mixed methods approach (4th ed.). Thousand Oaks, California: SAGE Publication, Inc.

Cummings and DiPasquak (1997), A Primer On The Secondary Mortgage Market City Research, Boston MA

Daramola (2004), Planning Policies and Affordable Housing at Nigeria, an Analysis of Abuja Master Plan Scheme and the Revolution of Certificate of Occupancy, Housing Studies Association Conference $9^{\text {th }}$ $10^{\text {th }}$ Sept. Bettest. UK.

Daramola Et-Al (2007) Public Private Partnership and Housing Delivery in Nigeria Lagos State and conference Abuja

Deng Y. Zhang D. Ling, C., (2004), An Early Assessment of Residential Mortgage Performance in China

Dvir D. et-al (2003), An Empirical Analysis of the Relationship Between Project Planning and Project Success "International Journal of Project Management

Edward P. and Shaoul J. (2003), Partnerships: for better for worse" Accounting, Auditing

Ehegbe N. (2017), Filling Nigerian's infrastructure gap, by NICRE Media and Publicity Unit News

Ernst and Young (2005), Australian Public Private Partnerships Survey issues Facing the Australian Public Private Partnership Market.

Evans et-al, (2007), The complete Real Estate Encyclopedia; Mc Graw Hill, New York, ISBN -13,978-47147638-6, ISBN-10:0407-147 638-5 Publication

EY, (2015), Public Private Partnerships and the Global Infrastructure challenge: How Public Private Partnerships Can Help Government Close the "Gap" Amid Financial limitation.

World Bank, (2018), The World Bank report 2018 report No MDISDC, 23618

FGN., (2013); Mid Term Report of the Transportation Agenda, Abuja, Federal Government of Nigeria

Ferguson B (1999), "Process Policy and Public Private Partnerships in Housing in Developing Countries: what can the United States learn? Paper presented at the Housing policy in the new millennium.

Frankly A. et-al (2000), Financial systems in Europe, the USA, and Asia, Oxford Review of Economic Policy, Vol. 20, no4, 2004, Oxford university Press and the oxford Review of Economic Policy Limited 2004.

Frauser D.R, Gup B.E and Kolari, (1995), Commercial Banking: The Management Risk "West Publishing Company, Tim Metropolis, St Paul.

Gandhi, S. (2012). Economics of Affordable Housing in Indian Cities: The Case of Mumbai. Environment and Urbanization ASIA, 3(1), 221-235. http://doi.org/10.1177/097542531200300112

Gibb, K. (2011). Delivering new affordable housing in the age of austerity: housing policy in Scotland. International Journal of Housing Markets and Analysis, 4(4), 357-368. http://doi.org/10.1108/17538271111172157

Goal II of SDG: Sustainable Development Goals (SDGS) and the 2030 Agenda Available at www.world bank.org.

Goussard H. (2015), Managing Nigerians huge infrastructure funding gap. Global construction Overview.

Grimsey, D. and Levis M. K., (2004), PPPS. The Worldwide Revolution in Infrastructure Provision and Project financial, Cheltenham, U.K! Edward Elgar Publishing limited.

Gutfentag 2004

Helm D. et-al (2009), Delivering a $21^{\text {st }}$ Century Infrastructure for Britain Policy Exchange, London.

Hodge G. A. \& Greve (2017), Public Private Partnership. An International Review Public Administration Review PP 545-558

Ibem, E. O. (2011). Public-Private Partnership (PPP) in Housing Provision in Lagos Megacity Region, Nigeria. International Journal of Housing Policy, 11(2), 133-154. http://doi.org/10.1080/14616718.2011.573204

Ibem, E. O., \& Aduwo, E. B. (2012). Public-Private Partnerships (PPPs) in Urban Housing in Nigeria: Evidence from Ogun State. International Journal Of Architecture and Urban Development, 2, 5-14.

Ismail, S. Azimi F. Thrasany R. (2012), Selection criteria for Islamic home financing in Malaysia international journal of business and society vol.15. No.1 2014, 97-110.

Jiya, M. B., Shaibu, S. I., Jaya, M. E., \& Abdullahi, I. (2018). Analysis of public and private - sectors partnership (ppp) in housing delivery in Niger state, Nigeria. Assumption University-EJournal of Interdisciplinary Research (AU-EJIR), 3(2), 119-128.

Koplan R. S. Norton PP (1992), The balanced scorecard - Measures that divot performance" Heorrand Business Review, January-February, PP 7199

Koppenjan (2005)

Kuma Shien (2015), Assessing the Challenges of Access to Housing Finance in the North Central States of Nigeria vol. 8, 10.4314, Ethiopian Journal of Environmental studies and Management.

Kutuma, N. (2017). Affordable Housing Public Private Partnerships: A Case Study of International Housing 
Solutions. University of Witwatersrand, Johannesburg.

Lea, (2000), International Comparison of Mortgage Products Offerings, Research Institute for Housing American and Mortgage Bankers Association, September, 2010 Special report

Lea, M. (2000), The role of the primary mortgage market in the development of a successful secondary markets' inter-American Development Bank, Washington DC.

Lee Ann Obringer \& Dave Roos 2017, "How mortgage work" $8^{\text {th }}$ October, 2002. Available (a)HowStuffWorks.comahttp \home.HowstuffworksCom/real estate/buying/mortgage.htm date

Li. B, et-al, (2005), Critical Success Factors for PPP/PFI Projects in the UK Construction Industry, Construction Management and Economics, Vol. 23 Issue 5, Pp 439-471

Li, H., (2006), Emergence of Chinese Middle Class and its implications; Asian Affairs; American Review

Liang and Wang (2019), Sustainable Performance Measurement for Public Private Partnership Projects: Empirical Evidence from China, MDPI System Ability, July, 2019

Liu, T., Chan, A., \& Wang, S. (2014). PPP Framework for Public Rental Housing Projects in China. In ICCREM 2014: Smart Construction and Management in the Context of New Technology C ASCE 2014 (pp. 573581).

Lopez-Silva et-al (2011), Housing Finance in Mexico current state and future system ability, Inter-American Development Bank, Department of Research and Chief Economist, Technical Notes NoIDB-TN-28)

Maclennan et-al, (2000), Asymmetries in Housing and financial market institutions and EMU; in T.Jenkinson (e d.) Readings in Macroeconomics Oxford, Oxford University Press.

Matteo, 1.et-al (2008), The credit channel of Manatong Policy: Evidence from Housing Market, Journal Macroeconomics 30 (2003), 69-96

McCord, M., McGreal, S., Berry, J., Haran, M., \& Davis, P. (2011). The implications of mortgage finance on housing market affordability. International Journal of Housing Markets and Analysis, 4(4), 394-417. http://doi.org/10.1108/17538271111172175

Memba, F. (2015), Factors Influencing Performance of Mortgage Financing among Commercial Banks in Kiisu Town, Kenya. International Journal of Economics/ Commercial Management. United Kingdom, Vol. III, issue 3, March, 2015, ISSN 23480386.

Mishkin F.S and Eakans S.G (2009), Financial markets and Institution Pearson Education Inc., Sixth Edition, Boston, Massaclusetts.

Muhammad, Zayyanu \& Toher, Fouzia (2018), Critical Success factors of Public Private Partnership projects a comparative analysis of the housing sector between Malaysia and Nigeria, international journal of construction management 13.10.1080/15623599-2017.1423163.

Murphy, L. (2014). ' Houston, we' ve got a problem ': The Political Construction of a Housing Affordability Metric in New Zealand. Housing Studies, 29(7), 893-909.

NDIC,.( 2015). Guardian Newspaper: Published by Verma (2012), Regulation 30 th June, 2014 of Specialized

NHP 2012, National Housing Policy, Federal Executive Council $20^{\text {th }}$ sure, 2012, Federal Ministry of Chima \& Lands, Housing and urban Development, Abuja

Ogbuefi V. U. and Adesanmi M. A. (2004), The effect of Macro Economic Factors on Housing Investment, The Estate Surveyor and Valuer Vol 27, No.1 March, 2004

Oyigbo, T. E.and Ugwu, O. O., (2017), Appraisal of Key Performance Indicators on Road Infrastructure Financed by Public Private Partnership in Nigeria, Nigeria Journal of Technology, Vol. 36, No. 4, October 2017, Pp $1049-1058$.

Ogumba O. A. (2013), Principles and Practice of Property Valuation in Nigeria, Atlantis Books P. O. Box 9625, University of Ibadan, Post office, Ibadan, Nig.

Ogunyemi C. O., (2017), Strategies Mortgage Executive Need to Prequalify Mortgage Loan Applicant, Walden Dissertation and Doctoral Studies Collections

Ojebode, A. J. (2016), Public Private Partnership(PPP) as a Mechanism for the Provision of Affordable Housing Delivery in Nigeria Unpublished Phd Thesis, University of Brighton

Ojo \& Ighalo, 2008, Factors Affecting Balance's choice of housing Loan Package in South West Nigeria Housing FinanceInternational Remember, 2008

Ojo, (2006), Primary Mortgage Market Pre-requisites for Sustainable Secondary Mortgage Market Development in Nigeria Being Paper Presented at the Mortgage Banking Association of Nigeria CEO Retreat held on 17-19 November, 2006 at Transcorp Hilton, Abuja

Okpala, (1994), Financing Housing in Developing Countries; A Review of the Pitfalls and potentials in the Development of formal Housing finance system, Urban studies Vol.; 31, No 9 (November, 2, 1994) PP $1591-1586$

Olanrele, O. O., Adegunle, T. O., Jalaoso, B. A., \& Said, R. Bin. (2019). Social Housing and REIT Funding for Affordable Housing in Africa Developing Nations. In The Bartlett School of Construction and Project Management International Conference Bartlett Real Estate Institute. 
Order (2000), The Structure and Evolution of American secondary mortgage markets with some implications for Developing markets "

Osborne (2000), Public Private Partnerships: Theory and Practice in International perspective (pp. 36-56) NewYork: Routledge.

Pal, S., \& Hossain, M. S. (2014). Innovations of Housing Finance Systems and the Implication in Bangladesh A Categorical Study on Financial Markets. American Journal of Trade and Policy, 1(1), 32. http://doi.org/10.15590/ajtp/2014/v1i1/54052

Phang, S.-Y. (2010). Affordable homeownership policy: Implications for housing markets. International Journal of Housing Markets and Analysis, 3(1), 38-52. http://doi.org/10.1108/17538271011027069

Rust, K., (2013), Housing Finance Internal Water 2012, African Union of Housing Finance, Annual Conference, ooh, No. PP 6.

Sani, M., Sani, A., \& Ahmed, S. U. (2018). Public private partnership housing projects implementation in Bauchi state. International Journal of Research in Engineering and Innovation, 2(1), 93-96.

Shaqra, E. A. A., Badarulzaman, N., \& Roosli, R. (2015). Residents 'Perception of the Affordability of Private Housing Schemes: Lessons from Aden, Yemen. Procedia - Social and Behavioral Sciences, 202(December 2014), 389-399. http://doi.org/10.1016/j.sbspro.2015.08.243

Shehar A.J. et-al, (2001), Project Success: A Multidimensional Strategic Concept Long range planning Vol.34, No.6 PP 699-725,2001

Sobuza, Y. (2010). "Social housing in South Africa : are public private partnerships ( PPP ) a solution?" University of Pretoria.

Tagliaro, C. (2014). S.O.S. Social or sustainable? In 40th IAHS World Congress on Housing.

Timothy Blackwood \& Sebastain Kohl, (2018), Working Paper, Varieties in Housing Finance in Historical Perspective. The impact of Mortgage Finance Systems on Urban Structure and Home Ownership, Discussion No 17/2.

Trangkanont, S., \& Charoenngam, C. (2014). Private partner's risk response in PPP low-cost housing projects. Property Management, 32(1), 67-94. http://doi.org/10.1108/PM-02-2013-0008

Trimbath \& Mantage (2002), Housing Affordability in Policy by three dimensions. Price, income, and Interest rate,Milken Institute, Number 31, September, 2002, 1250 fourth street, Sauka Marica collfonal 90401

Tsai, I., \& Peng, C. (2012). A panel data analysis for housing affordability in Taiwan. Journal of Economic Finance, 36, 335-350. http://doi.org/10.1007/s12197-009-9119-x

UN-Habitat, (2008), State of African Cities 2008, Framework for Addressing Urban Challenges in Africa, Nairobi, Kenya.

UN-Habitat, (2002), The Report of the first Session of the World Urban Forum, Nairobi, Kenya.

U.S.DOT., (2012), Financial Structuring of Public Private Partnerships (P3) US Department of Transport.

WBG (2018), Independent Evaluation Group, 181811 Street, NW Washington DC, 20453 IEG@ worldbank.org.

Wilson, W and Barton, C.(2019), What is Affordable housing, Briefing Paper,, Number 07747,23 ${ }^{\text {rd }}$ December, 2019, House of Commons Library.

Word Bank, (2009), Attracting Coveters to African PPP: A project preparation guide. New York World Bank www. Supply psychology. Org refreved on 29/9/19

www.gov.Uk referred 6th September, 2019

Yahang \& Hougu S. (2018), Advance in Civil Engineering Volume 2018. Article ND 95764962 10pages

Yunusa 2013, DT 2012, Financial structuring of PPS (p3), US Department of transportation 